Editorial

\title{
Streambank Erosion: Advances in Monitoring, Modeling and Management
}

\author{
Celso F. Castro-Bolinaga * ${ }^{(1)}$ and Garey A. Fox \\ Biological and Agricultural Engineering, North Carolina State University, Raleigh, NC 27695, USA; \\ garey_fox@ncsu.edu \\ * Correspondence: cfcastro@ncsu.edu; Tel.: +1-919-515-6712
}

Received: 31 August 2018; Accepted: 26 September 2018; Published: 28 September 2018

check for updates

\begin{abstract}
The special issue "Streambank Erosion: Monitoring, Modeling, and Management" presents recent progress and outlines new research directions through the compilation of 14 research articles that cover topics relevant to the monitoring, modeling, and management of this morphodynamic process. It contributes to our advancement and understanding of how monitoring campaigns can characterize the effect of external drivers, what the capabilities and limitations of numerical models are when predicting the response of the system, and what the effectiveness of different management practices is in order to prevent and mitigate streambank erosion and failure. The present editorial paper summarizes the main outcomes of the special issue, and further expands on some of the remaining challenges within the realm of monitoring, modeling, and managing streambank erosion and failure. First, it highlights the need to better understand the non-linear behavior of erosion rates with increasing applied boundary shear stress when predicting cohesive soil detachment, and accordingly, to adjust the computational procedures that are currently used to obtain erodibility parameters; and second, it emphasizes the need to incorporate process-based modeling of streambank erosion and failure in the design and assessment of stream restoration projects.
\end{abstract}

Keywords: cohesive soil; fluvial erosion; erodibility parameters; jet erosion test; stabilization practices; stream restoration

\section{Introduction}

Streambank erosion and failure is recognized as a significant source of sediment loading to streams (Figure 1). In many Conservation Effects Assessment Project (CEAP) watersheds in the United States, for example, sediment eroded from banks is one of the primary sources of bed material [1], accounting in some cases for as much as $80 \%$ of the total load [2]. Likewise, degraded banks can be a major contributor to nutrient loading in streams as reported by Laubel et al. [3] and Mittelstet et al. [4], who estimated that eroded sediment can contribute up to $40 \%$ and $47 \%$ of the total phosphorus in small rural and agricultural watersheds, respectively, and [5] that reviewed a wide range of studies and noted that streambank phosphorus contributions can be significant. From a geomorphic perspective, streambank erosion and failure modify the channel planform and cross-sectional geometry, ultimately altering the flow and sediment transport dynamics of the reach. This leads to hydro-morphodynamic adjustments, such as changes in flow depth, bed-material composition, and transport capacity, that take place at various spatial and temporal scales [6]. Furthermore, the magnitude of such adjustments has been enhanced over the last several decades by land-use dynamics within watersheds. For example, Schottler et al. [7] reported that the use of artificial drainage has triggered an increase in annual flow from agricultural basins, resulting in streams with a higher erosion capacity and therefore subject to severe channel widening due to bank erosion and failure. 


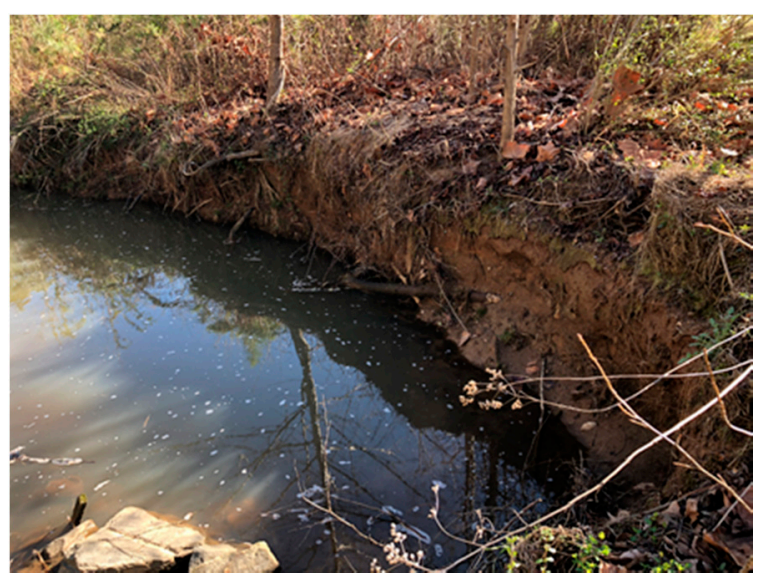

(a)

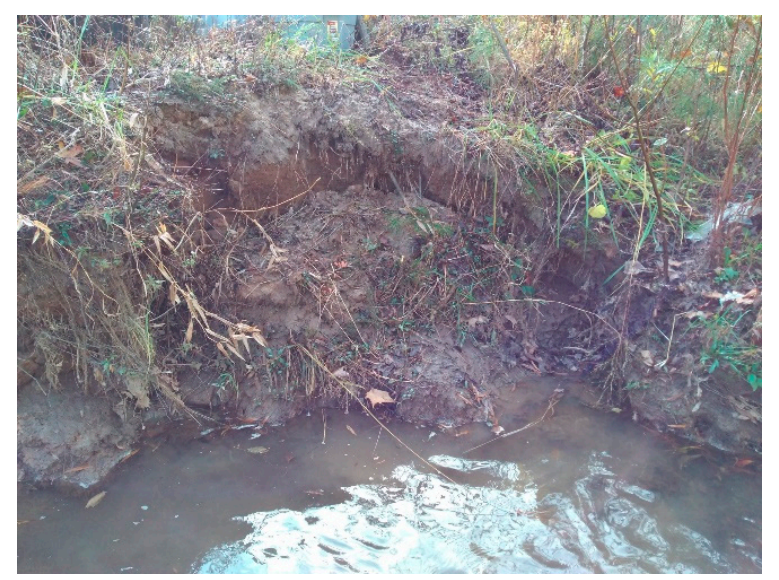

(b)

Figure 1. Post-restoration streambank (a) erosion and (b) failure in Richland Creek, Wake County, NC, USA. Pictures courtesy of the NCSU BAE-DMS stream restoration team.

The breadth of research being published on streambanks is rapidly expanding, especially since the early 1990s as illustrated in Figure 2. The purpose of this special issue was to compile recent progress and highlight new research directions relevant to streambank erosion and failure. The special issue contains 14 research articles that: (i) span across the realm of monitoring, modeling, and management, with the ultimate goal of advancing our understanding of the processes that govern these complex and dynamic phenomena; and (ii) build upon the rapidly expanding research literature (Figure 2).

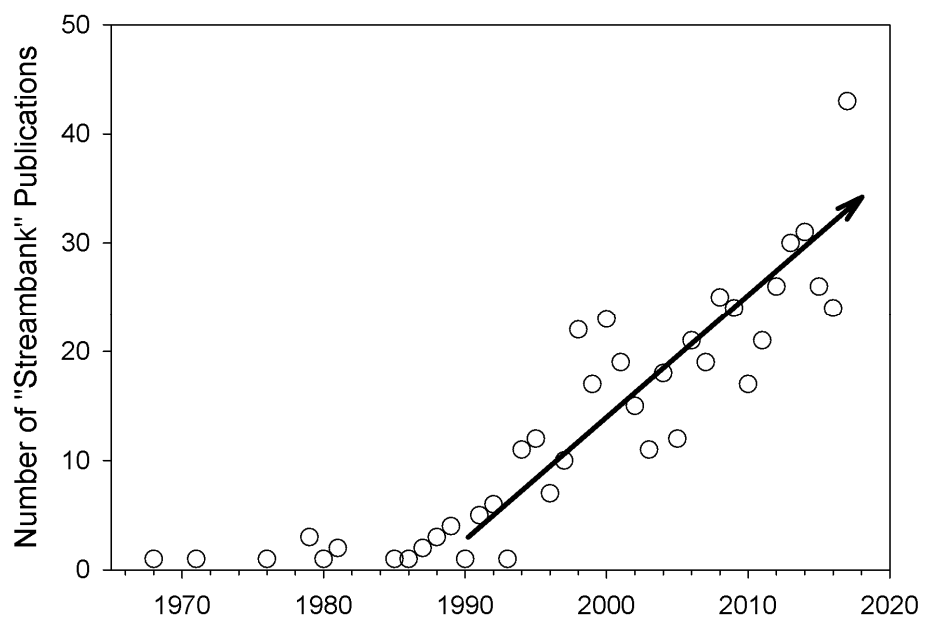

Figure 2. Number of publications on the topic of "streambank". Data are extracted from the Institute for Scientific Information's (ISI) Web of Science database. A total of 541 publications were identified under the topic of "streambank" as of August 2018.

\section{Main Outcomes of the Special Issue}

The research articles included in this special issue specifically targeted three areas that are key to better understanding streambank erosion and failure, namely, monitoring [8-11], modeling [12-17], and management [18-21]. As an ensemble, the articles highlight the value of monitoring campaigns to characterize the effect of external drivers (e.g., hydrologic events), the capabilities and limitations of numerical models for predicting the response of the system (e.g., stream restoration design), and the effectiveness of management practices to prevent and mitigate the impacts of streambank erosion and failure. 


\subsection{Monitoring}

Arnold and Toran [8] monitored erosion rates and turbidity levels in an urban stream to examine the effect of commonly found invasive species on bank retreat. Their results highlight the impact of different types of bank vegetation on erosion rates and their implications for calculating sediment supply. Dragićević et al. [9] reconstructed the lateral migration of a 15-km reach of a meandering river using 87 years of observations from cadastral maps and aerial photographs. This study is a relevant example of the use of historical data to characterize long-term trends of bank erosion relative to the hydrologic regimes that triggered them. Karimov and Sheshukov [10] monitored an ephemeral gully over a period of two years to identify the main factors responsible for soil detachment. They developed a critical shear stress function that accounts for changes in soil moisture content for achieving a more accurate prediction of erosion zones within ephemeral gullies. Lastly, the study by Kociuba and Janicki [11] showed how highly variable hydro-meteorological conditions influence the contribution of bank erosion to total sediment load by measuring erosion rates at fixed locations using the Global Navigation Satellite System (GNSS).

\subsection{Modeling}

Enlow et al. [12] simulated bank retreat using the one-dimensional (1D) process-based model CONCEPTS [22] to examine the impact of the variability associated with erodibility parameters on the model's predictions. Multiple Jet Erosion Tests (JETs) were performed along two streams located in separate watersheds to estimate the latter parameters, which were found to vary significantly in both cases. Nonetheless, their results indicate that the degree of variability associated with the model's predictions was not as high as that associated with the JET-derived erodibility parameters. Huang et al. [13] developed and validated a two-dimensional (2D) analytical model to predict critical hydraulic gradient for particle entrainment due to seepage flow. They examined the effect of various parameters (e.g., soil internal instability) on the results and proposed a methodology to calculate the initiation probability of particle movement. Lai [14] presents the development and application of a coupled vertical and lateral bank erosion model that is based on the 2D depth-averaged hydraulic and sediment transport model SHR-2D [23]. This study highlights the benefits of combining movingand fixed-mesh methods to enhance the robustness of the numerical model when predicting vertical channel bed changes and lateral bank erosion for complex systems.

Mahalder et al. [15] investigated the effect of using single and multiple pressure settings when performing JETs on the erodibility parameters computed from three different computational methods. Their comparison highlights the high degree of variability associated with the applied computational methods. Furthermore, they proposed a new technique for running JETs that consists of applying incrementally increasing pressure heads to account for the variation of soil properties during the test. Rousseau et al. [16] carried out numerical simulations to examine the sensitivity of the model's predictions to key biophysical conditions between two contrasting fluvial environments. The simulations were performed using the hydrodynamic solver TELEMAC-2D [24] coupled to a physics-based geotechnical module. Their results show that the model's predictions are highly dependent on the bank physical properties at the sub-reach scale, particularly for the case of soil cohesion and friction angle. Finally, Vonwiller et al. [17] validated a 2D hydro-morphodynamic model and performed sensitivity analyses to examine the suitability of various approaches (e.g., gravitational bank collapse) to simulate non-cohesive bank erosion in straight channels and the erosion of artificial gravel deposits.

\subsection{Management}

Addisie et al. [18] conducted a four-year study on 14 shallow gullies across the central Ethiopian highlands to identify cost-effective shallow gully head stabilization practices. The evaluated practices included re-grading slopes, and adding riprap, vegetation, or a combination of both. Results highlight 
the efficiency of various practices to prevent or control sediment erosion, ultimately contributing to managing sediment supply to downstream water bodies. Beck et al. [19] quantified watershed-scale sediment and total phosphorus loading from four types of bank material through the implementation of bank-face surveys, erosion pins, and soil analyses. The study watershed was dominated by weathered/colluvial bank material, which accounted for as much as $70 \%$ of the sediment and total phosphorus mass loss. This type of study contributes towards improving regional efforts to reduce and manage sediment and nutrient loading to streams.

Dave and Mittelstet [20] evaluated the effectiveness of six stabilization practices (e.g., jetties, rock vanes) that were implemented across 18 different bank locations. They used aerial imagery to quantify pre- and post-stabilization bank retreat and to assess the impact of a major storm event that took place during the evaluation period. Their results emphasize the importance of selecting an adequate stabilization technique to manage bank erosion, while considering the associated cost and performance under extreme conditions. Hoomehr et al. [21] carried out flume experiments to study the effect of water temperature, $\mathrm{pH}$, and salinity on bank erosion rates. Their results indicate that erosion rates are affected by water temperature, with higher rates as temperature rises. Likewise, they showed that erosion rates decrease with increasing $\mathrm{pH}$ under freshwater conditions, with the influence of $\mathrm{pH}$ becoming less pronounced as the level of salinity increases. These findings contribute toward more efficient restoration and management efforts, particularly in the context of urban streams.

\section{Remaining Challenges and Research Directions}

Numerous challenges still exist within the realm of monitoring, modeling, and managing streambank erosion and failure. The research articles included in this special issue addressed some of these challenges, as well as shed light on some topics that deserve further exploration. The latter topics include: (1) examining the effect of stratigraphic position on the quantification of sediment and total phosphorus loading to streams [19]; (2) accounting for the effects of vegetation, meandering, and weakening and weathering processes in the development, calibration, and application of numerical models [12,14,17]; (3) developing a better understanding of the physical mechanisms that govern gully progression and development, especially those in riparian areas [10]; (4) establishing a standardized procedure for running and post-processing the results of erodibility tests [15]; and (5) developing a better understanding of influential factors such as water chemistry on streambank erosion [21].

For example, let us elaborate on two relevant issues to streambank erosion and failure that require further attention. First is the prediction of cohesive bank erosion using derived erodibility parameters. While the JET remains the most suitable tool for measuring erodibility parameters in situ after its original development almost 30 years ago [25], updates to the device and a better understanding of the influence of various design aspects are needed. The device struggles from the inability to automatically collect scour measurements over time without periodically stopping the water jet from impinging on the soil. High resolution measurements of both the depth and shape of the scour hole could also better inform users of the soil's erodibility. Furthermore, Wardinski et al. [26] examined the suitability of the linear excess shear stress equation for predicting cohesive soil erosion from JET-derived erodibility parameters. Their results show that the linear assumption is suitable over a limited range of applied boundary shear stresses, which typically correlates to the values tested in-situ via the JET. However, they show that for larger values of applied boundary shear stress, the relationship between the latter variable and the erosion rate is not linear. The implication is that when JET-derived erodibility parameters are used in conjunction with the linear shear stress equation, erosion rates will likely be over-predicted for relatively large applied boundary shear stresses (e.g., during flood conditions). Therefore, there is a need to better understand the aforementioned non-linear behavior and potential changes in the detachment mechanisms in various shear stress ranges, and accordingly, to adjust the computational procedures that are currently used to post-process JET results for obtaining erodibility parameters (e.g., [27]). This research direction will contribute not only toward reducing the uncertainty associated with the application of the JET, but also toward enhancing the accuracy of numerical models 
intended to predict bank erosion and failure under a framework of enhanced magnitude and frequency of hydrologic events.

Second is the application of process-based models in stream restoration. Nowadays, methodologies for stream restoration projects are largely based on an assessment of channel form [28]. The widely applied Rosgen classification system [29,30], for example, attempts to evaluate and predict the behavior of these morphodynamic processes by focusing on the characterization of cross-sectional and planform geometry, an empirical bank erodibility hazard index (BEHI), a single channel-forming discharge, and a steady sediment transport capacity. Likewise, another commonly applied approach BANCS (Bank Assessment of Nonpoint source of Sediment) [31] is used to predict annual erosion rates and sediment loading from banks according to a statistical model based on BEHI and approximations of boundary shear stress obtained from field data [32]. Due to its practicality, form-based restoration as exemplified by these approaches has been extensively adopted by state and federal agencies, practitioners, and decision makers (e.g., $[33,34])$ as a tool for estimating rates of bank erosion when planning and designing restoration projects. However, several studies have shown the limitations of form-based restoration when accounting for the behavior of this morphodynamic process (e.g., [35-38]).

There is a need, therefore, to incorporate a formal analysis of the dynamic, physical processes that govern stream channel dynamics and streambank erosion and failure in order to focus on stream function (i.e., process-based restoration) rather than only on stream form (i.e., form-based restoration), as originally presented by Shields et al. [39]. Such an approach will contribute toward enhancing our understanding of existing conditions in degraded streams and improving the design of new restoration projects. For applying process-based models to simulate bank erosion and failure in the context of stream restoration, it is important to better understand: (i) the range of hydro-morphodynamic processes that indeed requires the use of this approach; (ii) under which conditions local-scale models (e.g., BSTEM [40]) are adequate and under which conditions reach-scale models (e.g., HEC-RAS coupled with BSTEM [41]) should be used; and (iii) how process-based models can be applied in restoration sites with limited input information. Nonetheless, the successful application of process-based models is restrained by broader challenges such as reliable estimates of sediment discharge, suitable measurements of bed load and suspended load transport rates, and accurate estimates of watershed sediment supply [28,42]. Furthermore, detailed monitoring campaigns to characterize pre- and post-restoration conditions will increase not only data availability on the effectiveness of the implemented practices, but also contribute toward improving the development and application of process-based models.

Recent advances in process-based modeling and improvements in data collection of influential erodibility and geotechnical parameters have created an opportunity where process-based approaches should be required as part of the design or at least as an evaluation of designs to ensure project success [43]. This research direction is timely not only because of the rapid increase of stream restoration projects, but also because it is directly aligned with the effort undertaken by part of the restoration community to move towards a process-based approach (e.g., [28,44-46]).

Author Contributions: Both authors contributed to writing and editing the manuscript.

Funding: This project was based on research that was partially supported by the North Carolina Agricultural Research Service with funding from the Hatch Act through the USDA National Institute of Food and Agriculture.

Acknowledgments: The guest editors would like to thank the authors that contributed to the special issue, the multiple reviewers whose comments and recommendations enhanced the quality of the research articles, and the Water Editorial team for their support throughout the submission, revision, and production processes.

Conflicts of Interest: The authors declare no conflict of interest. 


\section{References}

1. Tomer, M.D.; Locke, M.A. The challenge of documenting water quality benefits of conservation practices: A review of USDA-ARS's Conservation Effects Assessment Project watershed studies. Water Sci. Technol. 2001, 64, 300-310. [CrossRef]

2. Wilson, C.G.; Kuhnle, R.A.; Bosch, D.D.; Steiner, J.L.; Starks, P.J.; Tomer, M.D.; Wilson, G.V. Quantifying relative contributions from sediment sources in Conservation Effects Assessment Project watersheds. J. Soil Water Conserv. 2008, 63, 523-532. [CrossRef]

3. Laubel, A.; Kronvang, B.; Hald, A.B.; Jensen, C. Hydromorphological and biological factors influencing sediment and phosphorus loss via bank erosion in small lowland rural streams in Denmark. Hydrol. Process. 2003, 17, 3443-3463. [CrossRef]

4. Mittelstet, A.R.; Storm, D.E.; Fox, G.A. Testing of the Modified Streambank Erosion and Instream Phosphorus Routines in the SWAT Model. J. Am. Water Resour. Assoc. 2017, 53, 101-114. [CrossRef]

5. Fox, G.A.; Purvis, R.A.; Penn, C.J. Streambanks: A net source of sediment and phosphorus to streams and rivers. J. Environ. Manag. 2016, 181, 602-614. [CrossRef] [PubMed]

6. Pizzuto, J.E. Streambank Erosion and River Width Adjustment. In Sedimentation Engineering: Processes, Measurements, Modeling, and Practice; Garcia, M.H., Ed.; American Society of Civil Engineers (ASCE): Reston, VA, USA, 2008; pp. 387-438.

7. Schottler, S.P.; Ulrich, J.; Belmont, P.; Moore, R.; Lauer, J.W.; Engstrom, D.R.; Almendinger, J.E. Twentieth century agricultural drainage creates more erosive rivers. Hydrol. Process. 2014, 28, 1951-1961. [CrossRef]

8. Arnold, E.; Toran, L. Effects of Bank Vegetation and Incision on Erosion Rates in an Urban Stream. Water 2018, 10, 482. [CrossRef]

9. Dragićević, S.; Pripužić, M.; Živković, N.; Novković, I.; Kostadinov, S.; Langović, M.; Milojković, B.; Čvorović, Z. Spatial and Temporal Variability of Bank Erosion during the Period 1930-2016: Case StudyKolubara River Basin (Serbia). Water 2017, 9, 748.

10. Karimov, V.R.; Sheshukov, A.Y. Effects of Intra-Storm Soil Moisture and Runoff Characteristics on Ephemeral Gully Development: Evidence from a No-Till Field Study. Water 2017, 9, 742. [CrossRef]

11. Kociuba, W.; Janicki, G. Effect of Meteorological Patterns on the Intensity of Streambank Erosion in a Proglacial Gravel-Bed River (Spitsbergen). Water 2018, 10, 320. [CrossRef]

12. Enlow, H.K.; Fox, G.A.; Guertault, L. Watershed Variability in Streambank Erodibility and Implications for Erosion Prediction. Water 2017, 9, 605. [CrossRef]

13. Huang, Z.; Bai, Y.; Xu, H.; Cao, Y.; Hu, X. A Theoretical Model to Predict the Critical Hydraulic Gradient for Soil Particle Movement under Two-Dimensional Seepage Flow. Water 2017, 9, 828. [CrossRef]

14. Lai, Y.G. Modeling Stream Bank Erosion: Practical Stream Results and Future Needs. Water 2017, 9, 950. [CrossRef]

15. Mahalder, B.; Schwartz, J.S.; Palomino, A.M.; Zirkle, J. Estimating Erodibility Parameters for Streambanks with Cohesive Soils Using the Mini Jet Test Device: A Comparison of Field and Computational Methods. Water 2018, 10, 304. [CrossRef]

16. Rousseau, Y.Y.; Biron, P.M.; Van de Wiel, M.J. Comparing the Sensitivity of Bank Retreat to Changes in Biophysical Conditions between Two Contrasting River Reaches Using a Coupled Morphodynamic Model. Water 2018, 10, 518. [CrossRef]

17. Vonwiller, L.; Vetsch, D.F.; Boes, R.M. Modeling Streambank and Artificial Gravel Deposit Erosion for Sediment Replenishment. Water 2018, 10, 508. [CrossRef]

18. Addisie, M.B.; Langendoen, E.J.; Aynalem, D.W.; Ayele, G.K.; Tilahun, S.A.; Schmitter, P.; Mekuria, W.; Moges, M.M.; Steenhuis, T.S. Assessment of Practices for Controlling Shallow Valley-Bottom Gullies in the Sub-Humid Ethiopian Highlands. Water 2018, 10, 389. [CrossRef]

19. Beck, W.; Isenhart, T.; Moore, P.; Schilling, K.; Schultz, R.; Tomer, M. Streambank Alluvial Unit Contributions to Suspended Sediment and Total Phosphorus Loads, Walnut Creek, Iowa, USA. Water 2018, 10, 111. [CrossRef]

20. Dave, N.; Mittelstet, A.R. Quantifying Effectiveness of Streambank Stabilization Practices on Cedar River, Nebraska. Water 2017, 9, 930. [CrossRef]

21. Hoomehr, S.; Akinola, A.I.; Wynn-Thompson, T.; Garnand, W.; Eick, M.J. Water Temperature, pH, and Road Salt Impacts on the Fluvial Erosion of Cohesive Streambanks. Water 2018, 10, 302. [CrossRef] 
22. Langendoen, E.J. CONCEPTS-Conservational Channel Evolution and Pollutant Transport System; Research Report No. 16; USDA-ARS National Sedimentation Laboratory: Oxford, MS, USA, 2000.

23. Lai, Y.G. SRH-2D Version 2: Theory and User's Manual; U.S. Department of the Interior, Bureau of Reclamation, Technical Service Center: Denver, CO, USA, 2008.

24. Galland, J.C.; Goutal, N.; Hervouet, J.M. TELEMAC: A new numerical model for solving shallow water equations. Adv. Water Resour. 1991, 14, 138-148. [CrossRef]

25. Hanson, G.J. Development of a jet index to characterize erosion resistance of soils in earthen spillways. Trans. ASAE 1991, 34, 2015-2020. [CrossRef]

26. Wardinski, K.M.; Guertault, L.; Fox, G.A.; Castro-Bolinaga, C.F. Suitability of a Linear Model for Predicting Cohesive Soil Detachment during Jet Erosion Tests. J. Hydrol. Eng. 2018, 23, 06018004. [CrossRef]

27. Daly, E.R.; Fox, G.A.; Al-Madhhachi, A.T.; Miller, R.B. A Scour Depth Approach for Deriving Erodibility Parameters from Jet Erosion Tests. Trans. ASABE 2013, 56, 1343-1351.

28. Wohl, E.; Lane, S.N.; Wilcox, A.C. The science and practice of river restoration. Water Resour. Res. 2015, 51, 5974-5997. [CrossRef]

29. Rosgen, D.L. A Classification of Natural Rivers. Catena 1994, 22, 169-199. [CrossRef]

30. Rosgen, D.L. Applied River Morphology; Wildland Hydrology: Pagosa Springs, CO, USA, 1996.

31. Rosgen, D.L. A Practical Method of Computing Streambank Erosion Rate. In Proceedings of the Seventh Federal Interagency Sedimentation Conference, Reno, NV, USA, 25-29 March 2001; U.S. Inter-Agency Committee on Water Resources, Subcommittee on Sedimentation: Reno, NV, USA, 2001; pp. 9-18.

32. Rosgen, D.L. Watershed Assessment of River Stability and Sediment Supply; Wildland Hydrology: Fort Collins, CO, USA, 2009.

33. Harman, W.; Starr, R.; Carter, M.; Tweedy, K.; Clemmons, M.; Suggs, K.; Miller, C. A Function-Based Framework for Stream Assessment and Restoration Projects; U.S. Environmental Protection Agency, Office of Wetlands, Oceans, and Watersheds: Washington, DC, USA, 2012.

34. Yochum, S.E. Guidance for Stream Restoration and Rehabilitation; Technical Note TN-102.1; U.S. Department of Agriculture, Forest Service, Nation Stream and Aquatic Ecology Center: Fort Collins, CO, USA, 2015.

35. Juracek, K.E.; Fitzpatrick, F.A. Limitations and implications of stream classification. J. Am. Water Resour. Assoc. 2003, 39, 659-670. [CrossRef]

36. Smith, S.M.; Prestegard, K.L. Hydraulic Performance of a Morphology-Based Stream Channel Design. Water Resour. Res. 2005, 41, W11413. [CrossRef]

37. Simon, A.; Doyle, M.; Kondolf, M.; Shields, F.D.; Rhoads, B.; McPhillips, M. Critical Evaluation of How the Rosgen Classification and Associated “Natural Channel Design" Methods Fail to Integrate and Quantify Fluvial Processes in Channel Response. J. Am. Water Resour. Assoc. 2007, 43, 1117-1131. [CrossRef]

38. McMillan, M.; Liebens, J.; Metcalf, C. Evaluating the BANCS Streambank Erosion Framework on the Northern Gulf of Mexico Coastal Plain. J. Am. Water Resour. Assoc. 2017, 53, 1393-1408. [CrossRef]

39. Shields, F.D.; Copeland, R.R.; Klingeman, P.C.; Doyle, M.W.; Simon, A. Design for Stream Restoration. J. Hydraul. Eng. 2003, 129, 575-584. [CrossRef]

40. Bank Stability and Toe Erosion Model (BSTEM). Available online: https://www.ars.usda.gov/southeastarea/oxford-ms/national-sedimentation-laboratory / watershed-physical-processes-research/research/ bstem/overview/ (accessed on 30 August 2018).

41. CEIWR-HEC. HEC-RAS USDA-ARS Bank Stability \& Toe Erosion Model (BSTEM), Technical Reference E User's Manual; U.S. Army Corp of Engineers, Institute for Water Resources, Hydrologic Engineering Center: Davis, CA, USA, 2015.

42. Wilcock, P.R. Stream restoration in gravel-bed rivers. In Gravel Bed Rivers: Processes, Tools, and Environments; Church, M., Biron, P., Roy, A., Eds.; John Wiley: Chichester, UK, 2012; pp. 137-149.

43. Enlow, H.K.; Fox, G.A.; Boyer, T.A.; Stoecker, A.; Storm, D.E.; Starks, P.; Guertault, L. A modeling framework for evaluating streambank stabilization practices for reach-scale sediment reduction. Environ. Model. Softw. 2018, 100, 201-212. [CrossRef]

44. McDonald, A.; Lane, S.N.; Haycock, N.E.; Chalk, E.A. Rivers of dreams: On the gulf between theoretical and practical aspects of an upland river restoration. Trans. Inst. Br. Geogr. 2004, 29, 257-281. [CrossRef] 
45. Bernhardt, E.S.; Palmer, M.A. Restoring streams in an urbanizing world. Freshw. Biol. 2007, 52, 738-751. [CrossRef]

46. Bernhardt, E.S.; Palmer, M.A. River restoration-The fuzzy logic of repairing reaches to reverse watershed scale degradation. Ecol. Appl. 2011, 21, 1926-1931. [CrossRef] [PubMed]

(C) 2018 by the authors. Licensee MDPI, Basel, Switzerland. This article is an open access article distributed under the terms and conditions of the Creative Commons Attribution (CC BY) license (http:// creativecommons.org/licenses/by/4.0/). 